\title{
Net cages in fish farming: a scientometric analysis
}

\author{
Tanques rede em piscicultura: uma análise cienciométrica
}

Juliana Déo Dias, Nadson Ressyé Simões and Cláudia Costa Bonecker

Programa de Pós-graduação em Ecologia de Ambientes Aquáticos Continentais - PEA,

Núcleo de Pesquisas em Limnologia, Ictiologia e Aquicultura - NUPELIA,

Universidade Estadual de Maringá - UEM, Av. Colombo, 5790, CEP 87020-900, Maringá, PR, Brazil

e-mail: julianadeo@hotmail.com; nadsonressye@yahoo.com.br; claudiabonecker@gmail.com

\begin{abstract}
Aim: This study presents a scientometric analysis of studies on net cages in order to determine whether these studies are considering environmental issues or only seeking an increase in food production; Methods: The survey of articles was accomplished using the Thomson Reuters Database (ISI Web of Knowledge), with "cage culture" and "net cage" as keywords. We selected 238 articles that were published between 1990 and 2009; Results: There was a temporal increase in the number of articles published. These articles focused mainly on fish production and environmental impacts; Conclusion: The studies of net cages in fish farming mainly investigated fish production, although environmental issues relating to this recent human activity were also important. Policy makers should consider both sides of the coin (i.e., both the benefits and environmental impacts of fish production) in regulation of this activity.
\end{abstract}

Keywords: aquaculture, fish production, environmental impact, cage culture, temporal trend.

Resumo: Objetivo: $\mathrm{O}$ presente estudo teve como objetivo apresentar uma análise cienciométrica sobre os estudos de tanques rede, a fim de responder se estes estudos estão considerando as questôes ambientais ou, apenas, buscam um aumento na produçáo de alimentos; Métodos: O levantamento dos artigos foi realizado na base Thomson Reuters (ISI Web of Knowledge), sendo utilizadas "cage culture" e "net cage" como palavras-chave. Foram selecionados 238 artigos durante o período de 1990 a 2009; Resultados: Houve um incremento temporal no número de artigos publicados. Esses artigos enfocaram, principalmente, na produçáo pesqueira e impactos ambientais; Conclusáo: Os estudos de tanques rede abordaram, principalmente, produção pesqueira, entretanto, as questóes ambientais também foram importantes nesta recente atividade humana. Os decisores políticos devem considerar ambos os lados da moeda, ou seja, benefícios e impactos ambientais da produçấo pesqueira, antes de regular esta atividade.

Palavras-chave: aquicultura, produçáo pesqueira, impacto ambiental, cultivo em tanque, tendência temporal.

\section{Introduction}

The global population reached seven billion people in October 2011 (Roberts, 2011). Thus, the world is faced with the challenge of meeting the rapid demand for food production as a way to alleviate the problems of hunger among the poorest populations, and to ensure food security. Moreover, food production must be undertaken in ways that are environmentally and socially sustainable (Godfray et al., 2011).

Aquaculture is the farming of aquatic organisms, and originated about 4,000 years ago (Beveridge and Little, 2002). It is also considered an efficient way to produce food, as well as being economically important. This activity, as well as other production activities, negatively affects the environment at varying levels of intensity, depending on the way in which the cultivation is practiced (extensive, semi-intensive, or intensive). Among the methods of intensive cultivation, fish cultivation in net cages or ponds has become one of the most widely practiced in recent years because it is one of the best alternatives for reducing fishing pressure on natural fish stocks (Marengoni, 2006) and has a hypothetical fast return in investment (Agostinho et al., 2007).

Fish farming in net cages is an excellent alternative for fish production in water bodies where traditional fish farming is not viable (Schmittou, 1993). Additionally, this activity does not require 
new areas to be flooded for the construction of traditional fishponds (Rotta and Queiroz, 2003).

Fish cultivation in net cages uses a considerable quantity of food supply for the production of organisms in a small area at high densities, with consequent release of metabolites and food scraps directly into the environment. These residuals are potential sources of environmental impacts (Alves and Baccarin, 2005), exposing the environment to eutrophication processes. Other environmental impacts may additionally occur, such as changes in the trophic web, introduction of exotic species, decreases in biodiversity, and the spread of diseases (Kubtiza, 1999; Naylor et al., 2000; Guo and Li, 2003; Alves and Bacarin, 2005; Agostinho et al., 2007; Guo et al., 2009).

The implementation and development of fish farming in net cages in natural aquatic ecosystems can increase global production of fish. However, it is necessary for basic information about this activity to be generated, with the aim of reducing impacts on the aquatic environment and biological communities. Thus, the present study aimed to present a scientometric analysis of studies on net cages, based on scientific articles that investigated the use of net cages in fish farming, in order to determine whether these studies are considering environmental issues or are only seeking an increase in food production. Thus, some guiding questions were elaborated, as follows. i) What is the temporal trend of scientific production of studies on net cages? ii) What are the main types of environments studied (inland waters or marine)? iii) What is the main focus of the discussion (fish production, environmental impact, technical)? iv) What are the main journals that published the articles?

\section{Methods}

A survey of scientific articles focusing on use of net cages in fish farming activity was performed using the Thomson Reuters Database (ISI Web of Knowledge), considering the period between 1990 and 2009. The analysis was based on all the articles that contained the terms "cage culture" and "net cage" as a topic; we also used variations of these terms (cage culture* and net cage*). In total, we read 1,155 articles but only selected for scientometric analysis those which addressed the use of net cages for fish farming and/or evaluated the impact of this activity on other aquatic communities and the aquatic environment. Therefore, we analysed a total of 238 articles. Data for this analysis were collected in April 2010.
For each article we identified the year of publication, the type of environment (inland waters or marine) and the focus of discussion. The articles were grouped into the following categories by focus: fish production-those papers referring to fish production; environmental impact-those discussing any type of environmental impact derived from fish production in net cages; technical-those related to techniques and equipment for fish cultivation in net cages (e.g. physical structure of the net cages); and others-those on topics that did not fit into any other category and that each had a small number of scientific articles (e.g. description of new species recorded in studies of net cages). However, the category "others" were not used in the analyses.

The temporal trend of scientific production of fish by farming in net cages was evaluated by a simple regression analysis (Sokal and Rohlf, 1991), with the number of articles being the response variable and the publication year the explanatory variable. The number of articles that investigated the use of net cages for fish farming and/or evaluated the impact of this activity on other aquatic communities and the aquatic environment was standardized over time by dividing the number of articles on net cages by the total number of articles in the ISI database in a given year and multiplying the result by 1000 (Carneiro et al., 2008).

We used Analysis of Covariance (ANCOVA) (Gotelli and Ellison, 2004) in order to examine whether each of the categories studied (type of environment and focus of discussion) differed significantly over time, where the categories were the explanatory variables, the standardized number of articles was the response variable, and the publication year was the covariate. We tested the hypothesis of parallelism before testing for significant differences in slope. When significant differences in slope were found (i.e., lack of parallelism), a further "separate slopes" model was applied; on the other hand, when non-significant differences in slope were found, a traditional ANCOVA design was applied. The analyses were performed using the software Statistica version 7.1 (Statsoft, 2005).

\section{Results}

During the 20 years covered by the survey (1990-2009), 238 studies investigated the use of net cages in fish farming, and there was also a significant increase in the number of scientific articles over time $\left(\mathrm{R}^{2}=0.60 ; \mathrm{P}<0.001\right)$ (Figure 1). 
Regarding the type of environment studied, the greatest number of published scientific articles considered marine environments $(\mathrm{N}=129)$, while fewer considered inland water environments $(\mathrm{N}=77)$. The rate of increase in scientific publications did not differ between those considering marine and inland water (homogeneity of slopes test; $\left.F_{1,37}=1.21 ; P=0.270\right)$, and the number of articles for both increased over time (ANCOVA, $\mathrm{F}_{1,37}=5.83 ; \mathrm{P}=0.020$ ) (Figure 2).

The major focus of discussion in scientific articles was fish production, which was discussed in a total of 102 publications. The second most frequently discussed topic was environmental

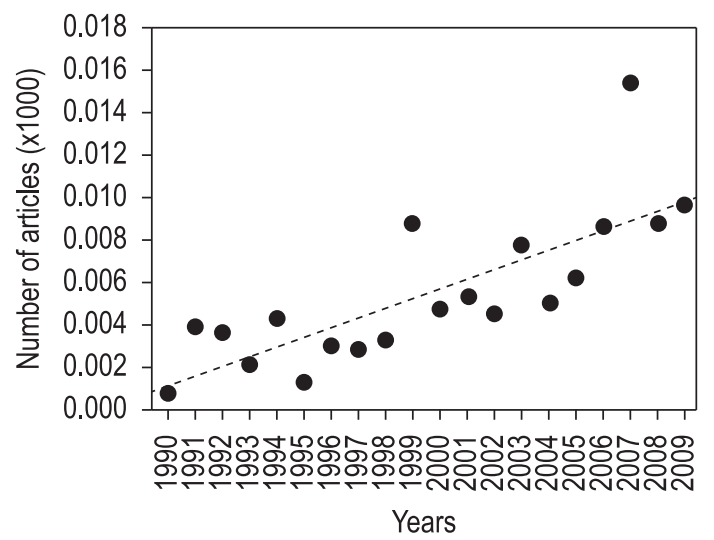

Figure 1. Temporal trend of the standardized number of articles investigating the use of net cages in fish farming (multiplied by 1000) between 1990 and 2009 in the ISI database.

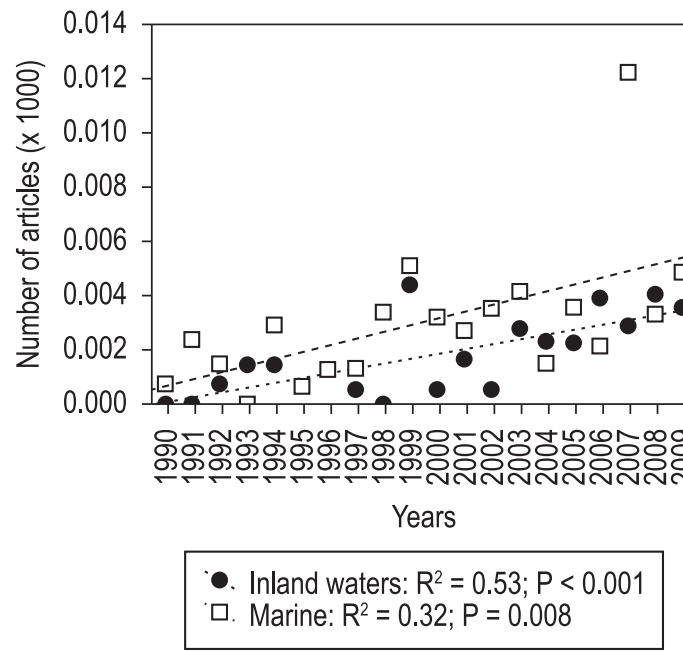

Figure 2. Number of articles investigating the use of net cages in fish farming between the years 1990 and 2009, according to the type of environment. The number of articles was standardized in relation to the total number of articles indexed in the ISI database. impact, with 88 published articles, and the third covered technical aspects, with 29. The rates of increase in scientific publications differed among focus of discussion (homogeneity of slopes; $\left.\mathrm{F}_{2,54}=3.32 ; \mathrm{P}<0.040\right)$. Thus, a "separate slopes" model was run; it showed a significant difference between approaches $\left(\mathrm{F}_{3,54}=3.28 ; \mathrm{P}<0.040\right)$. The technical focus had a lower rate of increase than impact and production focus (Figure 3).

We verified that the journal Aquaculture presented the greatest number of studies $(\mathrm{N}=55)$. The periodic with the second largest number of studies was Aquaculture Research, with 23 articles. Thus, the most articles focusing on use of net cages in fish farming activity were published in journals on aquaculture. Many journals were included in the category "others", since they contained less than five relevant articles each (Figure 4).

\section{Discussion}

Aquaculture in net cages has developed rapidly in the last two decades, and is undergoing changes due to the growing demand for production of organisms in aquatic environments in both developed and developing countries (Tacon and

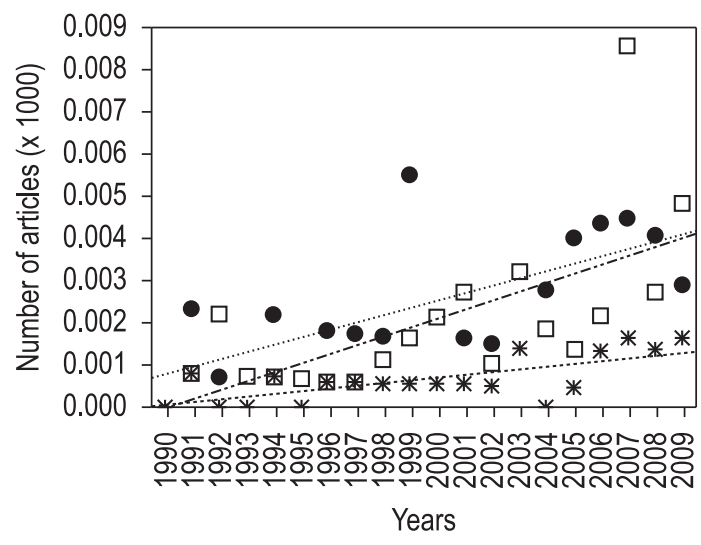

- Fish production: $\mathrm{R}^{2}=0.49 ; \mathrm{P}<0.001$

ㅁ. Environmental impact: $R^{2}=0.42 ; P=0.002$

*. Technical: $R^{2}=0.47 ; P<0.001$

Figure 3. Number of published articles investigating the use of net cages in fish farming between the years 1990 and 2009, according to the focus of discussion. The number of articles was standardized in relation to the total number of articles indexed in the ISI database (fish production $=$ those referring to fish production; environmental impact $=$ those discussing any type of role of net cages in environmental impact; technical = those related to techniques and equipments for fish cultivation in net cages). 


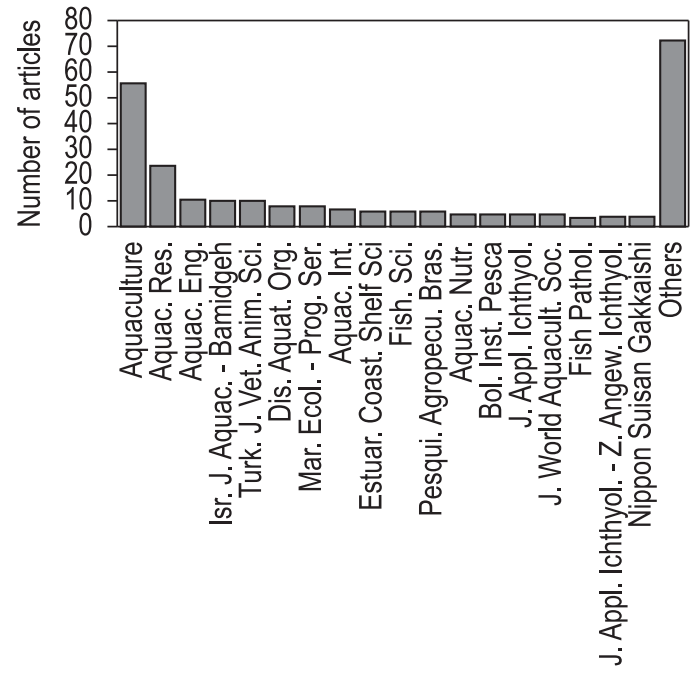

Figure 4. Journals in which the articles investigating the use of net cages in fish farming were published between the years 1990 and 2009, in the ISI database.

Halwart, 2007). Global production of aquatic organisms increased by $187 \%$ between 1990 and 2001 (Zaniboni-Filho et al., 2005). The increase in the number of scientific articles in the last 20 years probably contributed to the increase of global production, due to the need to research and learn techniques to implement it.

The Brazilian government has encouraged fish cultivation in net cages to tackle problems of hunger. In general, this activity has been implemented in reservoirs, and to support it the Special Secretariat for Aquaculture and Fisheries (SEAP), then under the umbrella of the Ministry of Agriculture and Livestock (which has now become the Ministry of Fisheries and Aquaculture) was created in 2003.

The reason for the increased number of publications concerning marine environments compared to inland waters is that the former present advantages, including an increased body of knowledge about the commercial cultivation of marine fish and reduction of economic costs, due to the availability of larger areas for installation of net cages, the fact that the most productive waters are in coastal regions, and the possibility of a greater dilution of waste (Whittaker and Likens, 1973). In addition, the choice of the marine environment for the development of most of the net cage farming studies may be related to aquaculture activities, which historically started in marine environments. Nevertheless, some inland water environments, such as reservoirs, also present potential for net cage farming (Abery et al., 2005), due to the availability of a large number of reservoirs, low water velocity in backwater areas where the tanks are installed, water turnover (residence time) and depth (at least one meter above the bottom).

The large number of publications concerning fish production is related to a trend of increasing fish farming aimed at improving global food security and increasing farmers' income, ensuring the preservation of natural fish stocks, and finally maintaining biodiversity. In articles with this focus, the most frequently discussed issues were those related to nutrition, growth, survival, reproduction, and mortality of fish. In addition, environmental impact was another focus that was emphasized in the scientometric analysis, considering the effects of the process of installing and running production in net cages on the functioning and biodiversity of aquatic ecosystems. This fact is important because it shows concern for environmental issues and not just for increasing food production. Indeed, the waste products of this activity result in degradation of the surroundings. Everything that is not consumed or assimilated, as well as other excretion products of cultivated animals, contributes to environmental eutrophication (Agostinho et al., 2007).

The risk of fish escape and introduction of exotic species into aquatic environments also represents an environmental impact, since these individuals are likely to interfere in the food web of the environment, both directly as competitors and/or predators and indirectly through the contribution of nutrients (excretion or predation) (Agostinho et al., 2007). The net cages are vulnerable to escapes due to strong winds, predators, floating objects and vandalism, and constitute a source of introduction of exotic species. This environmental impact is regarded an important factor responsible for loss of biodiversity and natural resources (Agostinho et al., 2007). However, the Committee on Agriculture, Livestock and Supply and the Committee of Environment and Sustainable Development both approve the Bill 5989/09, which encourages the cultivation of exotic species of fish in net cages, equating them to local native species in order to eliminate a number of impediments in Brazilian legislation that aim to minimize the environmental risk of introducing exotic species (Lima Junior et al., 2012). This Bill is still pending before the House of Representatives and, if approved, could increase the environmental impacts resulting from introduction of exotic species.

The choice of aquaculture journals for publication of articles was related to the specificity of these journals, which publish articles related to 
the exploration, improvement and management of all aquatic food resources. Moreover, these journals also publish articles on the environmental impacts of aquaculture, thus contributing to the wider subject matter in these journals.

In conclusion, we observed a temporal trend of an increase in the number of published articles during the period between 1990 and 2009. In this study, we showed that studies of net cage farming are considering environmental issues and are not only aimed at an increase in food production. Thus, policy makers should consider concomitantly both the environmental impacts and fish production issues generated through aquaculture in net cages. As highlighted in this study, before proposing legislation and measures to encourage this activity, policy makers must take into account both sides of the coin and not only the benefits of an increase in fish production.

\section{Acknowledgements}

The authors wish to express their gratitude to professors Dr. Horácio Ferreira Júlio Junior and Dr. Sidinei Magela Thomaz, for useful suggestions and two anonymous reviewers for their helpful comments. We thank CAPES and CNPq for the scholarships of the authors; and Nupélia (Núcleo de Pesquisa em Limnologia, Ictiologia e Aquicultura) for the infrastructure and resources that enabled this study.

\section{References}

ABERY, NW., SUKADI, F., BUDHIMAN, AA., KARTAMIHARDJA, ES., KOESHENDRAJANA, S. and SILVA, SS. 2005. Fisheries and cage culture of three reservoirs in west Java, Indonesia; a case study of ambitious development and resulting interactions. Fisheries Management and Ecology, vol. 12, p. 315-330. http://dx.doi.org/10.1111/ j.1365-2400.2005.00455.x

AGOSTINHO, AA., GOMES, LC. and PELICICE, FM. 2007. Ecologia e manejo de recursos pesqueiros em reservatórios do Brasil. Maringá: Eduem, 501 p.

ALVES, RCP. and BACCARIN, AE. 2005. Efeito da produção de peixes em tanques-rede sobre sedimentação de material em suspensão e de nutrientes no córrego da Arribata (UHE Nova Avanhandava, Baixo rio Tietê, SP). In NOGUEIRA, MG., HENRY, R. and JORCIN, A., orgs. Ecologia de Reservatórios: Impactos potenciais, açóes de manejo e sistemas em cascata. São Carlos: Rima. p. 329-347.

BEVERIDGE, MCM. and LITTLE, DC. 2002. Aquaculture in traditional societies. In COSTA-
PIERCE, BA., org. Ecological Aquaculture. Oxford: Blackwell. p. 3-29.

CARNEIRO, FM., NABOUT, JC. and BINI, LM. 2008. Trends in the scientific literature on phytoplankton. Limnology, vol. 9, p. 153-158. http://dx.doi. org/10.1007/s10201-008-0242-8

GODFRAY, CJ., BEDDINGTON, JR., CRUTE, IR., HADDAD, L., LAWRENCE, D., MUIR, JF., PRETTY, J., ROBINSON, S., THOMAS, SM. and TOULMIN, C. 2011. Food Security: The challenge of feeding 9 billion people. Science, vol. 327, p. 812-816.

GOTELLI, NJ. and ELLISON, AM. 2004. A primer of ecological statistics. Massachusetts: Sinauer Associates. 479 p.

GUO, L. and LI, Z. 2003. Effects of nitrogen and phosphorus from fish cage-culture on the communities of a shallow lake in middle Yangtze River basin of China. Aquaculture, vol. 226, p. 201-212. http:// dx.doi.org/10.1016/S0044-8486(03)00478-2

GUO, L., ZHONGJIE, L., XIE, P. and NI, L. 2009. Assessment effects of cage culture on nitrogen and phosphorus dynamics in relation to fallowing in a shallow lake in China. Aquaculture International, vol. 17 , p. 229-241. http://dx.doi.org/10.1007/ s10499-008-9195-5

KUBTIZA, F. 1999. Tanques-rede, raçóes e impacto ambiental. Revista Panorama da Aquicultura, vol. 9, no. 51, p. 44-50.

LIMA JUNIOR, DP., PELICICE, FM., VITULE, JRS. and AGOSTINHO, AA. 2012. Aquicultura, política e meio ambiente no Brasil: novas propostas e velhos equívocos. Natureza \& Conservação, vol. 10, no. 1, p. 1-4.

MARENGONI, NG. 2006. Produção de tilápia do Nilo Oreochromis niloticus (linhagem chitralada), cultivada em tanques-rede, sob diferentes densidades de estocagem. Archivos de Zootecnia, vol. 55, no. 210, p. $27-138$.

NAYLOR, RL., GOLDBURG, RJ., PRIMAVERA, JH., KAUTSKY, N., BEVERIDGE, MCM., CLAY, J., FOLKE, C., LUBCHENCO, J., MOONEY, H. and TROELL, M. 2000. Effect of aquaculture on world fish supplies. Nature, vol. 405, p. 1017-1024. PMid:10890435. http://dx.doi. org/10.1038/35016500

ROBERTS, L. 2011. 9 Billion? Science, vol. 333, no. 6042, p. 540-543. PMid:21798924. http:// dx.doi.org/10.1126/science.333.6042.540

ROTTA, MA. and QUEIROZ, JF. 2003. Boas práticas de manejo (BPMs) para produção de peixes em tanques-rede. Corumbá: Embrapa Pantanal. 27 p.

SCHMITTOU, HR. 1993. High density fish culture in low volume cages. Cingapura: American Soybean Association. 78 p. 
SOKAL, RR. and ROHLF, FJ. 1991. Biometry: the principles and practice of statistics in biological research. New York: W. H. Freeman and Company. 859 p.

Statsoft Inc. 2005. Statistica. version 7.1. Tulsa: Statistica. 3v.

TACON, AGJ. and HALWART, M. 2007. Cage aquaculture: a global overview. In HALWART, M., SOTO, D. and ARTUR, JR., orgs. Cage aquaculture - Regional reviews and global overview. Roma: FAO Fisheries Technical. no. 498, p. 3-16.
WHITTAKER, RH. and LIKENS, GE. 1973. Primary production: The biosphere and man. Human Ecology, vol. 1, p. 357-369. http://dx.doi.org/10.1007/ BF01536732

ZANIBONI-FILHO, E., NUNEER, APO., GUERESCHI, RM. and HERMES-SILVA, S. 2005. Cultivo de peixes em tanques-rede e impactos ambientais. In CARDOSO, EL. and FERREIRA, RMA., orgs. Cultivo de peixes em tanques-rede: Desafios e oportunidades para um desenvolvimento sustentável. Belo Horizonte: Epamig. p. 57-80.

Received: 22 February 2011

Accepted: 16 May 2012 